\title{
Growth Inhibitory Effects of Adhatoda vasica and Its Potential at Reducing Listeria monocytogenes in Chicken Meat
}

\section{OPEN ACCESS}

Edited by:

David Rodriguez-Lazaro,

University of Burgos, Spain

Reviewed by:

Alessandra De Cesare

Università di Bologna, Italy

Antonio Valero,

Universidad de Córdoba, Spain

${ }^{*}$ Correspondence:

Vivek K. Bajpai

vbajpai04@yahoo.com

Yun Suk Huh

yunsuk.huh@inha.ac.kr

Young-Kyu Han

ykenergy@dongguk.edu

Specialty section:

This article was submitted to

Food Microbiology,

a section of the journal

Frontiers in Microbiology

Received: 05 April 2017 Accepted: 23 June 2017

Published: 17 July 2017

Citation:

Shukla S, Ahirwal L, Bajpai VK Huh YS and Han Y-K (2017) Growth Inhibitory Effects of Adhatoda vasica and Its Potential at Reducing Listeria monocytogenes in Chicken Meat.

Front. Microbiol. 8:1260.

doi: 10.3389/fmicb.2017.01260

\author{
Shruti Shukla ${ }^{1}$, Laxmi Ahirwal ${ }^{2}$, Vivek K. Bajpai ${ }^{3 *}$, Yun Suk Huh ${ }^{4 *}$ and Young-Kyu Han ${ }^{1 *}$ \\ ${ }^{1}$ Department of Energy and Materials Engineering, Dongguk University Seoul, Seoul, South Korea, ${ }^{2}$ Laboratory of Plant \\ Pathology and Microbiology, Department of Botany, Dr. Hari Singh Gour University, Sagar, India, ${ }^{3}$ Department of Applied \\ Microbiology and Biotechnology, Yeungnam University, Gyeongsan-si, South Korea, ${ }^{4}$ Department of Biological Engineering, \\ Inha University, Incheon, South Korea
}

The inhibitory effects of Adhatoda vasica ethanolic leaf extract (AVELE) against Listeria monocytogenes were examined to assess its potential to preserve minimally processed meat products safely. The total phenolic, flavonoid, and alkaloid levels in AVELE were $10.09 \pm 4.52 \mathrm{mg}$ of gallic acid equivalents $(\mathrm{GAE}) / \mathrm{g}, 22.43 \pm 1.62 \mathrm{mg}$ of quercetin equivalents/g, and $19.43 \pm 3.90 \mathrm{mg} / \mathrm{g}$, respectively. AVELE (1, 5, 10, or 20\%) had considerable antibacterial effects against L. monocytogenes NCIM 24563 in terms of the inhibitory zones $(7.4-13.6 \mathrm{~mm})$, MIC (100 mg/mL or $10 \%$ formulated solution), reduced cell viability, potassium ion efflux, and the release of 260-nm absorbing materials and extracellular ATP. AVELE was used as a rinse solution (5, 10, and 20\%) for raw chicken breast meat. A $20 \%$ rinsing solution applied for 60 min inhibited the L. monocytogenes NCIM 24563 counts significantly on raw chicken breast meat. Moreover, L. monocytogenes NCIM 24563 did not grow in the meat sample when the rinse time was increased to $90 \mathrm{~min}$ at the same concentration. L. monocytogenes showed a greater reduction to 3 CFU/g after rinsing with a 10 and 20\% AVELE solution for 30 min than with a 5\% AVELE solution. The rinsing processes with AVELE produced the final cooked chicken products with higher sensory attribute scores, such as taste, juiciness, and tenderness, compared to the control group along with a decrease in microbial contamination. Chicken meat rinsed with AVELE (rinsing time of $90 \mathrm{~min}$ ) showed better sensory attribute scores of juiciness and tenderness, as well as the overall sensory quality compared to the untreated group. This research highlights the effectiveness of AVELE against L. monocytogenes NCIM 24563, suggesting that AVELE can be used as an effective antimicrobial marinade and/or a rinse for meat preservation.

Keywords: L. monocytogenes NCIM 24563, Adhatoda vasica, ethanolic extract, antimicrobial, food model

\section{INTRODUCTION}

Despite the increased understanding of the microbiology and control of infectious diseases, epidemics caused by hazardous microorganisms and the emergence of unknown disease-causing microbes pose significant public health concerns (Dussault et al., 2016). Contaminated foods are also an issue because of the serious illnesses they cause. In the United States, it has been estimated 
that 76 million people annually fall victim to foodborne diseases, which result in five thousand deaths per year (Dussault et al., 2016).

Listeria monocytogenes is a gram-positive, facultative, anaerobic bacterium, and the causative agent of listeriosis. Healthy adult humans infected with L. monocytogenes often remain asymptomatic (Takahashi et al., 2015), but the mortality rate in these cases ranges from 20 to 30\% (McLauchlin et al., 2004). In Western countries, L. monocytogenes is responsible for many cases of food poisoning through dairy products, processed meats, salads, and other ready-to-eat foods that do not require heating or cooking prior to consumption (Goulet et al., 2008). Recent foodborne listeriosis outbreaks (Schlech et al., 1983; CDC, 2014) have prompted research into innovative ways of inhibiting hazardous pathogens, particularly in semi-cooked packaged meat-based food products (Aureli et al., 2000). One such method involves the use of antimicrobials to provide an increased margin of food safety and quality (Appendini and Hotchkiss, 2002).

Marination or rinsing with various seasonings or antimicrobials often reduce the growth of hazardous microbial pathogens (Perko-Mäkelä et al., 2000). The United States Department of Agriculture (USDA) recommended that individuals at risk of contracting listeriosis should avoid eating store-made or other meat-based packaged semi-cooked food products; links were established with listeriosis in a variety of semi-cooked food products (USFDA, 2011). Besides the aim of microbial reduction, additional criteria, such as consumer acceptability, human health issues, and environmental safety need to be considered before any antimicrobial agent can be implemented in food products. To ensure food-related safety, consumers are demanding natural alternatives to chemical additives in food products, but with increased food safety, and shelf-life (Piskernik et al., 2011).

Chemical preservatives are commonly added to foods to enhance food safety, but consumers are becoming increasingly concerned about the harmful effects of chemical preservatives (Marta et al., 2012). Accordingly, there is growing interest in the use of natural and renewable antimicrobials in food preservation. Moreover, plant extracts, specifically those extracted using $70 \%$ ethanol, exhibit no toxicity; hence, they could be considered safe for food applications (Ahmad and Tabassum, 2013; Mugisha et al., 2014). Plants offer a rich variety of bioactive compounds, such as phenolics, flavonoids, terpenoids, and alkaloids, with a diverse range of pharmacological activities (Bakkali et al., 2008). For example, plant extracts from rosemary, oregano, clove, thyme, and citrus fruit (lemon, orange, and grapefruit) are among the most studied natural antimicrobials for food applications (Corbo et al., 2008).

Adhatoda vasica (Malabar nut) is a perennial plant that is wellknown in Ayurveda for its medicinal properties (Maurya and Singh, 2010; Kaur et al., 2012). The plant grows throughout India, even at higher altitudes in the Himalayan region, and is also found in Myanmar, Sri Lanka, Burma, and Malaysia. A. vasica has been used by indigenous people as a medicine for thousands of years, particularly in the treatment of respiratory disorders (coughs, colds, asthma, and bronchitis) (Kaur et al., 2012). A. vasica has been reported to possess several biological activities, which include anti-inflammatory, anti-spasmodic, anti-bleeding, anti-diabetic, and anti-jaundice effects (Maurya and Singh, 2010). Considering the potential use of natural antimicrobial agents and their application in the current scenario of food preservation, A. vasica has been found to exhibit potent antimicrobial activity against various foodborne pathogenic bacteria along with its in vivo efficacy as a food preservative to control the proliferation of L. monocytogenes in processed food (Subramaniam et al., 2015).

Antimicrobial coatings or washings might reduce the incidence of foodborne illnesses caused by L. monocytogenes in meat products. Therefore, this study examined the in vitro and in vivo efficacy of AVELE derived from A. vasica on the microbial load of L. monocytogenes NCIM 24563 in chicken meat as well as its overall efficacy as a rinse on the sensory quality of chicken meat. This is the first report to address the use of $A$. vasica in chicken to control L. monocytogenes NCIM 24563.

\section{MATERIALS AND METHODS}

\section{Chemicals and Reagents}

Folin-Ciocalteu reagent, gallic acid, quercetin, potassium ferricyanide, ascorbic acid, and pyrogallol were purchased from Sigma Aldrich (St. Louis, MO, USA). Brain heart infusion broth (BHI broth), peptone, and brain heart infusion agar (BHI agar) were purchased from Sigma Aldrich (St. Louis, MO, USA). The spectrophotometric measurements were performed using enzyme-linked immunosorbent assay (ELISA) (Tecan, Switzerland).

\section{Plant Materials and Extract Preparation}

Plant material, A. vasica (dried leaf powder), was donated by Jeevan Herbal Products (Sagar, MP, India). Briefly, the powder $(100 \mathrm{~g})$ was extracted with a 20 -fold volume of $70 \%$ ethanol for $3 \mathrm{~h}$ at $65^{\circ} \mathrm{C}$, filtered through Whatman No. 2 filter paper, concentrated using a vacuum evaporator, and freeze-dried. The resulting AVELE was then stored at $-20^{\circ} \mathrm{C}$ until further analysis.

\section{Analysis of Total Phenolic, Flavonoid, and Alkaloid Contents of AVELE}

The total phenolic contents of AVELE were determined using Folin-Ciocalteau reagent with gallic acid as the standard phenolic compound (Singleton et al., 1999). Briefly, $20 \mu \mathrm{L}$ of the extract solution $(1 \mathrm{mg} / \mathrm{mL})$ was added to $100 \mathrm{~mL}$ of Folin-Ciocalteu reagent, and $80 \mathrm{~mL}$ of $10 \%$ aqueous sodium carbonate was added $3 \mathrm{~min}$ later. This mixture was left to stand for $1 \mathrm{~h}$ at room temperature, and the absorbance of the resulting blue colored mixture was measured at $765 \mathrm{~nm}$ against a $70 \%$ ethanol $(200$ $\mathrm{mL}$ ) blank. The total phenolic content was calculated as the gallic acid equivalent (GAE) by the calibration curve obtained using a standard gallic acid solution. The results were expressed as $\mathrm{mg}$ GAE/g dry mass.

The total flavonoid content of AVELE was determined calorimetrically (Sakanaka et al., 2005). Briefly, $100 \mu \mathrm{L}$ of AVELE or standard reagent and $400 \mu \mathrm{L}$ of ethanol were mixed with $500 \mu \mathrm{L}$ of a $2 \% \mathrm{AlCl}_{3}$ solution prepared using distilled water. After $1 \mathrm{~h}$ incubation at room temperature, the absorbance 
was measured at $430 \mathrm{~nm}$. Quercetin was used as a reference compound to generate a standard curve, and results are expressed as $\mathrm{mg} \mathrm{QE} / \mathrm{g}$ dry mass.

The total alkaloid content of AVELE was determined as described previously (Shamsa et al., 2008). A sample of AVELE was weighed into a $250 \mathrm{~mL}$ beaker, and $200 \mathrm{~mL}$ of $10 \%$ acetic acid in ethanol was added. The beaker was then covered and allowed to stand for $4 \mathrm{~h}$ at room temperature. The sample was then filtered and concentrated on a water bath to one quarter of its original volume. Concentrated ammonium hydroxide was then added dropwise to the extract until precipitation was complete. The solution was then left to stand until the precipitate had settled. The resulting precipitate was collected, washed with dilute ammonium hydroxide, and filtered. The residue (total alkaloid) was dried and weighed. The results are presented as $\mathrm{mg} / \mathrm{g}$ of dried extract.

\section{Preparation of Bacterial Cultures of Test Pathogens}

The pathogenic strain, L. monocytogenes NCIM 24563, which was isolated from ready-to-eat-food (serotype 1/2a), was obtained from the Microbial Type Culture Collection, Chandigarh, India. The strain was maintained on $\mathrm{BHI}$ agar at $4^{\circ} \mathrm{C}$ and grown in $\mathrm{BHI}$ broth at $37^{\circ} \mathrm{C}$ for $24 \mathrm{~h}$.

Other bacterial strains, such as Salmonella typhimurium ATCC 43174, were obtained from the Korea Food and Drug Administration, and maintained on nutrient agar (NA) at 4 C.

\section{Determination of Inhibitory Effects of AVELE}

The disc diffusion method was used to assay the anti-listerial effects of AVELE (Bajpai et al., 2014). L. monocytogenes NCIM 24563 was grown in $\mathrm{BHI}$ broth and incubated at $37^{\circ} \mathrm{C}$ for 18-24 h. The bacterial growth of the culture was adjusted to $\sim 10^{7} \mathrm{CFU} / \mathrm{mL}$, and an aliquot of the bacterial culture $(100 \mu \mathrm{L})$ was spread over the plate count agar and dried on a clean bench for a few minutes. AVELE solutions $(50 \mu \mathrm{L})$ at different concentrations $(10,50,100$, or $200 \mathrm{mg} / \mathrm{mL}$, corresponding to $1,5,10$, and $20 \%$, respectively) were added to the discs, which were then placed on agar plates, and incubated at $37^{\circ} \mathrm{C}$ for $18-$ $24 \mathrm{~h}$. The zones of inhibition against L. monocytogenes NCIM 24563 were measured in millimeters. The assays were performed in triplicate.

\section{Measurement of Minimum Inhibitory Concentration (MIC) of AVELE}

A MIC microplate assay, as described by Shiu and Gibbons (2006), was used to determine the lowest AVELE concentration that inhibited the visual growth of L. monocytogenes NCIM 24563. Briefly, $100 \mu \mathrm{L}$ of sterile distilled water was aliquoted into the wells of a 96-well sterile plate, and serial dilutions of an AVELE solution $(200 \mathrm{mg} / \mathrm{mL})$ were added to the cells. A standard culture $\left(100 \mu \mathrm{L} ; 10^{7} \mathrm{CFU} / \mathrm{mL}\right)$ of L. monocytogenes NCIM 24563 was then dispensed into each well of a 96-well sterile plate. The plate was then sealed and incubated at $37^{\circ} \mathrm{C}$ for $24 \mathrm{~h}$. A culture medium without the bacterial inoculum and sterilized distilled water without AVELE were used as the negative controls. To visualize the level of bacterial growth, $40 \mu \mathrm{L}$ of $p$-iodonitrotetrazolium violet (INT) $(0.04 \mathrm{mg} / \mathrm{mL})$ per well was added and the plate was incubated at room temperature for $6 \mathrm{~h}$. After incubation, the plate was examined for any color changes. The results obtained in triplicate were recorded and analyzed using Excel ${ }^{\circledR}$.

\section{Effect of AVELE on Viable Cell Counts}

Tubes containing the bacterial suspension $\left(\sim 10^{7} \mathrm{CFU} / \mathrm{mL}\right)$ of L. monocytogenes NCIM 24563 in BHI broth $(10 \mathrm{~mL})$ were inoculated with AVELE at $100 \mathrm{mg} / \mathrm{mL}$ (its MIC), and maintained at $37^{\circ} \mathrm{C}$ (Shin et al., 2007); samples were taken at $0,40,80$, 120,160 , and $200 \mathrm{~min}$. The viable counts on $\mathrm{BHI}$ plates were determined using the following method. A $0.1 \mathrm{~mL}$ sample of each treatment was diluted 10 -fold with the buffer peptone water and spread over the surface of BHI agar. The colonies were counted after incubation for $24 \mathrm{~h}$ at $37^{\circ} \mathrm{C}$. The controls were inoculated without AVELE under the same experimental conditions. The experiments were performed in triplicate.

\section{Effect of AVELE on Potassium Ion Efflux}

A method devised by Bajpai et al. (2014) was used to determine the amount of potassium ion leakage. The concentration of free potassium ions in the bacterial suspensions of L. monocytogenes NCIM 24563 was measured after exposing the bacterial cells to AVELE at $100 \mathrm{mg} / \mathrm{mL}$ in sterile peptone water for $0,30,60,90$, or $120 \mathrm{~min}$. The extracellular potassium concentrations were measured using a photometric procedure on a Calcium/Potassium kit (Quantofix, GmbH, Wiesbaden, Germany). The controls were devoid of AVELE. The results are expressed as the potassium concentrations $(\mathrm{mmol} / \mathrm{L})$ in the growth medium in triplicate.

\section{Effect of AVELE on the Release of 260-nm Absorbing Cellular Materials}

This assay was conducted using $2 \mathrm{~mL}$ aliquots of bacterial inoculum in sterile peptone water containing $100 \mathrm{mg} / \mathrm{mL}$ of AVELE at $37^{\circ} \mathrm{C}$. After exposure for 0,30 , or $60 \mathrm{~min}$, the L. monocytogenes NCIM 24563 cells were centrifuged at 3,500 rpm, and the absorbance of the obtained supernatant was measured at $260 \mathrm{~nm}$ using a 96-well plate ELISA reader (Carson et al., 2002). Control sets without AVELE were also tested in an identical manner. The results are expressed in terms of the absorbance with respect to the specific time.

\section{Effect of AVELE on the Release of Extracellular Adenosine 5'-Triphosphate (ATP)}

A previous method was adopted to determine the effects of AVELE on the membrane integrity of the tested pathogens in terms of its ability to cause the leakage of extracellular ATP (Bajpai et al., 2014). To collect the cells, actively grown cultures of L. monocytogens NCIM $24563\left(\sim 10^{7} \mathrm{CFU} / \mathrm{mL}\right)$ were centrifuged $(10 \mathrm{~min}$ at $1,000 \times \mathrm{g})$, and the collected cell pellet was washed three times with $0.1 \mathrm{M}$ sodium phosphate buffer $(\mathrm{pH} 7.0$ ) followed by centrifugation, as specified above. A $0.5 \mathrm{~mL}$ cell 
suspension $\left(10^{7} \mathrm{CFU} / \mathrm{mL}\right)$ prepared in sodium phosphate buffer was placed into an Eppendorf tube for the AVELE treatment at the MIC. The samples were kept at room temperature for $30 \mathrm{~min}$ followed by centrifugation $(5 \mathrm{~min}$ at 2,000 $\times \mathrm{g}$ ). To prevent the loss of ATP, the samples were incubated in ice immediately. The extracellular ATP concentrations (upper supernatant layer) were measured using an ATP bioluminescent assay kit (Sigma, MO, USA) according to the manufacturer's instructions.

\section{Application of AVELE in Food Sample} Determination of the $\mathrm{pH}$ of AVELE as a Rinse Solution The $\mathrm{pH}$ of the prepared AVELE rinse solutions at different concentrations was determined using an In-Lab427 $\mathrm{pH}$ meter fitted with a combined glass electrode (Mettler-Toledo, GmbH, 8603 Schwarzenbach, Switzerland), which had been calibrated previously to $\mathrm{pH} 4.0$ and 7.0.

\section{Application of AVELE as a Rinse in Chicken Meat}

Raw breast chicken meat sealed-pack ( $250 \mathrm{~g}$ ) was purchased from a local grocery store and stored at $4{ }^{\circ} \mathrm{C}$ until analyzed. A portion (25 g) of the raw breast chicken meat was weighed and placed in a flask containing $225 \mathrm{~mL}$ of buffered peptone water. All the weighed samples were enriched and plated to check for the presence or absence of L. monocytogenes NCIM 24563 prior to artificial inoculation.

The chicken breast meat samples $(25 \mathrm{~g})$ were then inoculated with $1 \mathrm{~mL}$ of an overnight culture of L. monocytogenes NCIM 24563 inoculum $\left(10^{6} \mathrm{CFU} / \mathrm{mL}\right)$ in sterile Whirl-Pak stomacher bags (Scheme 1), which were then stored overnight at $4^{\circ} \mathrm{C}$ to allow bacterial attachment. The samples were then divided into four equal pieces using a sterile blade and treated with $60 \mathrm{~mL}$ of water (control) or AVELE autoclaved for $30 \mathrm{~min}$ at $121^{\circ} \mathrm{C}$ at concentrations of 50,100 , or $200 \mathrm{mg} / \mathrm{mL}$. The following rinse times were used: 5, 10, 15, 30, 60, and $90 \mathrm{~min}$. After rinsing, pieces of each set were removed and placed separately into sterile stomacher bags. One piece was then used to plate $0 \mathrm{~h}$ (no storage); the other chicken pieces were kept at $4^{\circ} \mathrm{C}$ overnight, held for $24 \mathrm{~h}$, and plated.

To determine the L. monocytogenes NCIM 24563 counts in chicken meat, the samples were homogenized for $2 \mathrm{~min}$ at $200 \mathrm{rpm}$ and diluted serially in $9 \mathrm{~mL}$ of buffer peptone water. Homogenized and diluted chicken samples were plated onto selective media, as mentioned above, and incubated for $24 \mathrm{~h}$ at $37^{\circ} \mathrm{C}$. The colonies were counted, and the results are expressed as the CFU/g of the chicken meat sample. Each experiment was performed in triplicate.

Parallel sets of experiments with L. monocytogens NCIM 24563 and S. typhimurium) were also conducted using different food matrices (pork meat and ready-to eat fresh salad) to validate the industrial applications of AVELE as a rinse. Each experiment was performed in triplicate.

\section{Sensory Analysis of AVELE Treated Chicken Meat Samples}

An evaluation of the sensory properties was conducted by an expert panel of 20 trained panelists, aged between 20 to 25 and 30 to 40 years. The panelists were selected based on their sensitivity to 4 taste attributes, odor, taste (sweet, sour, bitter, or umami), tenderness, and juiciness, to a threshold level along with a potential to confirm the taste sensory characteristics of cooked chicken (treated with the AVELE rinse solution). These sensory attributes are considered important, and a wide range of parameters are used to determine the taste properties and taste disorders of food samples. A previously reported method was followed for the descriptive sensory analysis of the test samples (Stone and Sidel, 1985). The overall sensory characteristics (odor, taste, tenderness, and juiciness) of the AVELE treated, cooked chicken samples were evaluated using a 9-point scale hedonic test principle (Stone and Sidel, 1985) and given numerical values of 1 (extremely dislike) to 9 (extremely like).

\section{Color Analysis}

The surface color of the cooked AVELE rinse-treated chicken breast samples was evaluated using a Minolta Chroma Meter CR-300 (Minolta Co. Ltd., Osaka, Japan), calibrated against a white tile. The color measurements $\left(\mathrm{L}^{*}, \mathrm{a}^{*}\right.$, and $\mathrm{b}^{*}$ values representing lightness, redness, and yellowness, respectively) were taken after cooling the rinse-treated cooked samples at room temperature. For each sample, the $\mathrm{L}^{*}, \mathrm{a}^{*}$, and $\mathrm{b}^{*}$ values were taken at three locations, which included two adjacent locations to the central measurement. For color analysis, the $\mathrm{L}^{*}$ value indicates lightness, ranging from 0 to 100 , representing dark to light (Byun et al., 2013). The a* value represents the degree of red-green color, in which a higher $a^{*}$ value indicates a redder color score. The $b^{*}$ value represents the degree of yellowblue color; a high positive $b^{*}$ value indicates a yellower color score.

\section{Statistical Analysis}

All experiments were conducted in triplicate, and all data (number of colony counts) were converted to log CFUs. The means were calculated and a Duncan's test in IBM SPSS Statistics 21 was used to analyze the data. $P$ values $<0.05$ were considered significant.

\section{RESULTS AND DISCUSSION}

\section{Total Phenolic, Flavonoid, and Alkaloid Contents of AVELE}

Phenolic compounds conferring various biological and functional properties are considered to be important secondary metabolites because of their hydroxyl groups and occur ubiquitously in plants (Nithya et al., 2016). The plant materials rich in phenolics are being used increasingly in the food industry because they retard the oxidative degradation of lipids and improve the quality and nutritional value of food (Naczk and Shahidi, 2004). Flavonoids are plant-based natural components that have a range of health beneficial effects and play a significant role as scavengers or reactive oxygen species (ROS), which improve the quality of the foods (Bravo, 1998). Alkaloids are natural components of plants that have been implicated in various biological activities and used as food flavor enhancers (Koleva et al., 2012). Interestingly, in this study, AVELE contained large amounts of phenolics, flavonoids, 


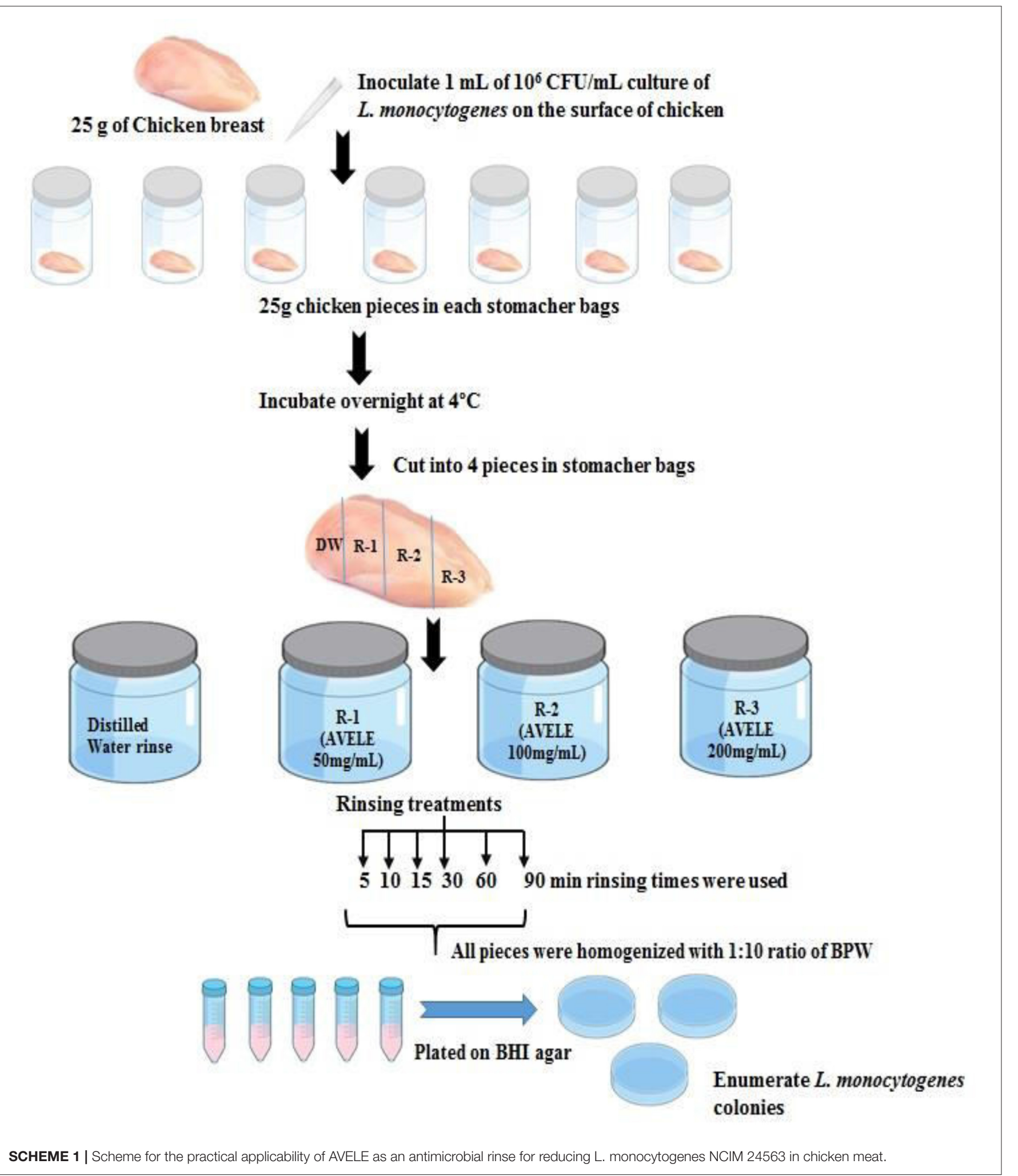

and alkaloids with mean values of $10.09 \pm 4.52 \mathrm{mg}$ GAE/g, $22.43 \pm 1.62 \mathrm{mg} \mathrm{QE} / \mathrm{g}$, and $19.43 \pm 3.90 \mathrm{mg} / \mathrm{g}$, respectively (Table 1). Vijayanandraj et al. (2014) also evaluated the phenolics and alkaloids in the A. vasica leaf extract and the plant was rich in alkaloids rather than phenolics. Claeson et al. (2000) reported that the plant was a rich source of quinazoline alkaloids, such as vasicine, vasicinone, deoxyvasicinone, vasicol, and adhavasicinone. Several studies have shown that plant 
TABLE 1 | Total phenolic, flavonoid, and alkaloid contents in the Adhatoda vasica ethanolic leaf extract (AVELE).

\begin{tabular}{lcc}
\hline \multicolumn{3}{c}{ Adhatoda vasica ethanolic leaf extract (AVELE) } \\
\hline $\begin{array}{l}\text { Total phenolic } \\
\text { content (mg GAE) }\end{array}$ & $\begin{array}{c}\text { Total flavonoid } \\
\text { content (mg QE) }\end{array}$ & Total alkaloid (mg/g) \\
\hline $10.09 \pm 4.52$ & $22.43 \pm 1.62$ & $19.43 \pm 3.90$ \\
\hline
\end{tabular}

secondary metabolites have antimicrobial activity against hazardous pathogens (Benbott et al., 2012; Maatalah et al., 2012). The biological activities of plants, including their antimicrobial activities, have been attributed to different classes of secondary metabolites, including phenolic, alkaloid, and flavonoid components (Stevenson and Hurst, 2007). In addition, these compounds contribute to the quality and nutritional value of foods by modifying their color, taste, aroma, and flavor, as well as have beneficial health effects (Iturraga et al., 2012).

\section{Anti-listerial Inhibitory Effects}

The in vitro inhibitory activity of AVELE against L. monocytogenes NCIM 24563 was assessed by measuring the diameters of the zones of inhibition. AVELE at a concentration of $20 \%(200 \mathrm{mg} / \mathrm{mL})$ had an antibacterial effect against L. monocytogenes NCIM 24563 with an inhibitory zone diameter of $13.6 \pm 1.01 \mathrm{~mm}$, whereas 5 and $10 \%$ (50 and $100 \mathrm{mg} / \mathrm{mL}$, respectively) AVELE produced the zones of inhibition of 7.4 \pm 2.12 and $9.8 \pm 1.54 \mathrm{~mm}$, respectively (Table 2 ). In contrast, no inhibitory zone was observed at $1 \%(10 \mathrm{mg} / \mathrm{mL})$ AVELE (Table 2). Various natural plant-based extracts have shown antimicrobial properties against various pathogens (Holley and Patel, 2005; Bakkali et al., 2008). The appropriate use of such extracts in the food industry as antimicrobials require careful selection of the undesirable organoleptic effects (Iturraga et al., 2012). Iturraga et al. (2012) reported that natural plant extracts (rosemary, oregano, and citrus) have potent antibacterial effects, as determined by the zones of inhibition against Listeria sp. In addition, Meignanalakshmi et al. (2013) reported that the methanolic extract $(200 \mathrm{mg} / \mathrm{mL})$ of $A$. vasica had significant antimicrobial activity against Staphylococcus aureus, Streptococcus agalactiae, Klebsiella pneumonia, Streptococcus dysgalactiae, and Escherichia coli with zones of inhibition ranging from 18.3 to $28.3 \mathrm{~mm}$.

\section{MIC of AVELE}

AVELE inhibited the growth of L. monocytogenes NCIM 24563 with a MIC of $10 \%(100 \mathrm{mg} / \mathrm{mL})$ (Table 2), whereas $1 \%$ dimethyl sulfoxide (DMSO), as a negative control, did not inhibit its growth. In the present study, a lower MIC was obtained for AVELE, which might be due to the additive or synergistic effects of the various bioactive compounds present in AVELE. Shen et al. (2014) reported that different types of blueberry extracts had anti-listerial effects with MICs ranging from 300 to $750 \mathrm{mg} / \mathrm{mL}$.
TABLE 2 | Antibacterial activity of Adhatoda vasica ethanolic leaf extract (AVELE) against Listeria monocytogenes NCIM 24563.

\begin{tabular}{lcc}
\hline Concentration (AVELE) & Inhibitory zone (mm) & MIC \\
\hline $10 \mathrm{mg} / \mathrm{mL}(1 \%)$ & - & $100 \mathrm{mg} / \mathrm{mL}$ \\
$50 \mathrm{mg} / \mathrm{mL}(5 \%)$ & $7.4 \pm 2.12^{\mathrm{C}}$ & \\
$100 \mathrm{mg} / \mathrm{mL}(10 \%)$ & $9.8 \pm 1.54^{\mathrm{b}}$ & \\
$200 \mathrm{mg} / \mathrm{mL}(20 \%)$ & $13.6 \pm 1.01^{\mathrm{a}}$ \\
\hline
\end{tabular}

MIC, Minimum inhibitory concentration; $\mathrm{mm}$, Millimeter. All values were expressed as mean $\pm S D$ of three parallel measurements $(n=3)$. Values in the same column with different superscripts are significantly different according to Duncan's Multiple Range Test $(p<0.05)$.

\section{Effect of AVELE on Cell Viability}

AVELE inhibited the growth of L. monocytogenes NCIM 24563 at its MIC (Figure 1); after $40 \mathrm{~min}$ exposure, AVELE at its MIC strongly inhibited L. monocytogenes, and after $80 \mathrm{~min}$, the CFU numbers declined steeply by $\sim 4 \pm 0.01 \log$ CFU after exposure for up to $160 \mathrm{~min}$. Furthermore, L. monocytogenes NCIM 24563 was completely eradicated after 200 min exposure (Figure 1). Higginbotham et al. (2014) reported the anti-listerial activity of the aqueous extract of Hibiscus sabdariffa and its use to reduce the viable counts at undetectable levels in hot dogs. They suggested that the $H$. sabdariffa extract might be a useful antimicrobial rinse for meat-based food products to control the listerial counts. Furthermore, they reported that at an extract concentration of $240 \mathrm{mg} / \mathrm{mL}$ and rinse time of $60 \mathrm{~min}$, the $H$. sabdariffa extract almost eradicated L. monocytogenes counts in hot dogs.

\section{Effect of AVELE on Potassium Ion Efflux}

When L. monocytogenes NCIM 24563 cells were treated at its MIC $(100 \mathrm{mg} / \mathrm{mL})$, the AVELE caused the rapid release of potassium ions from L. monocytogenes NCIM 24563 cells (800 $\mathrm{mmol} / \mathrm{L})$, but no potassium leakage was observed in the control sets (Figure 2). The release of essential ions or electrolytes from the bacterial cells after treatment with an antimicrobial could be considered a good indication of its antimicrobial effect (Bajpai et al., 2014). In the present study, when tested against L. monocytogenes NCIM 24563, AVELE induced the release of potassium compared to the control. The bacterial plasma membrane was reported to play a pivotal role in controlling the efflux of essential ions from bacterial cells. The membrane ion permeability is closely related to the chemical composition and structures of the cell membranes. Therefore, a dramatic increase in potassium efflux from the bacterial cells indicates membrane disruption and probable cell death (Cox et al., 2001).

\section{Effect of AVELE on Absorption at 260-nm Cellular Materials}

The investigation on the antibacterial effect of AVELE was extended to determine the nature of its possible anti-listerial mechanism. Although the synergistic mechanisms underlying the activities of various plant extracts are not well-understood, it was assumed that membrane perturbation and the adverse oxidoreduction potential by bioactive components, such as flavonoids, phenolics, and alkaloids, play major roles in establishing their 


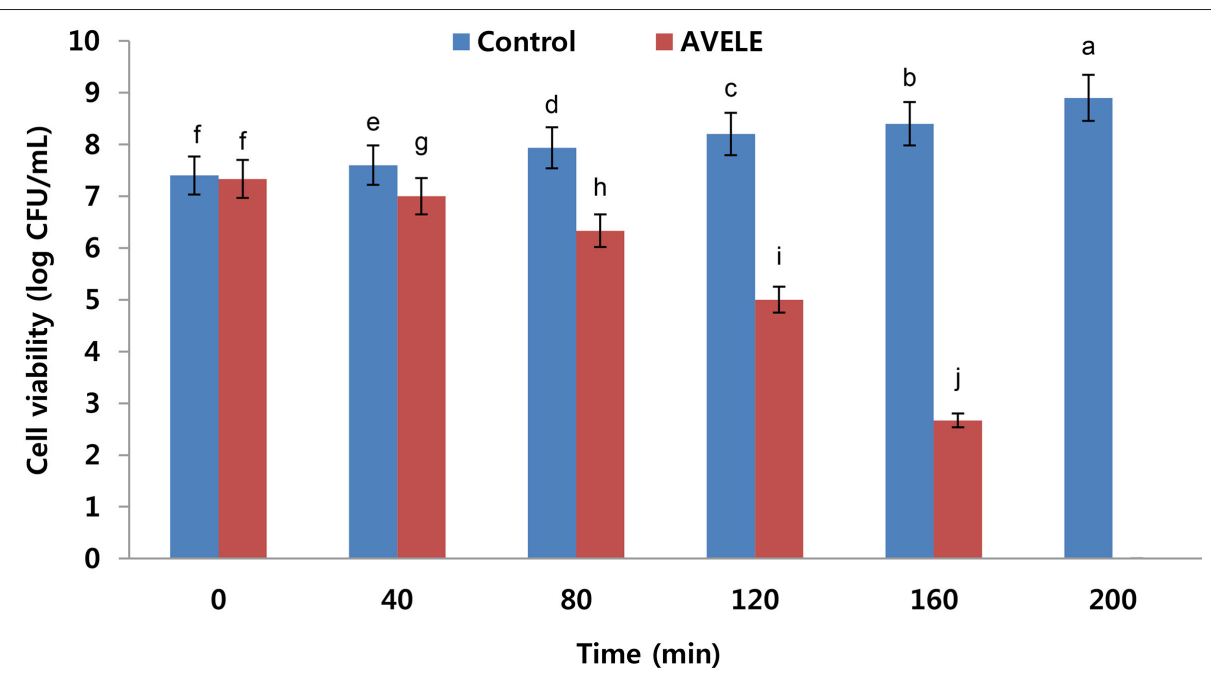

FIGURE 1 | Effects of Adhatoda vasica ethanolic leaf extract (AVELE) on the viability of the tested foodborne pathogen, L. monocytogenes NCIM 24563. The data are expressed as the mean $\pm S D(n=3)$. The values in the same column with different superscripts are significantly different according to a Duncan's multiple range test $(p<0.05)$.

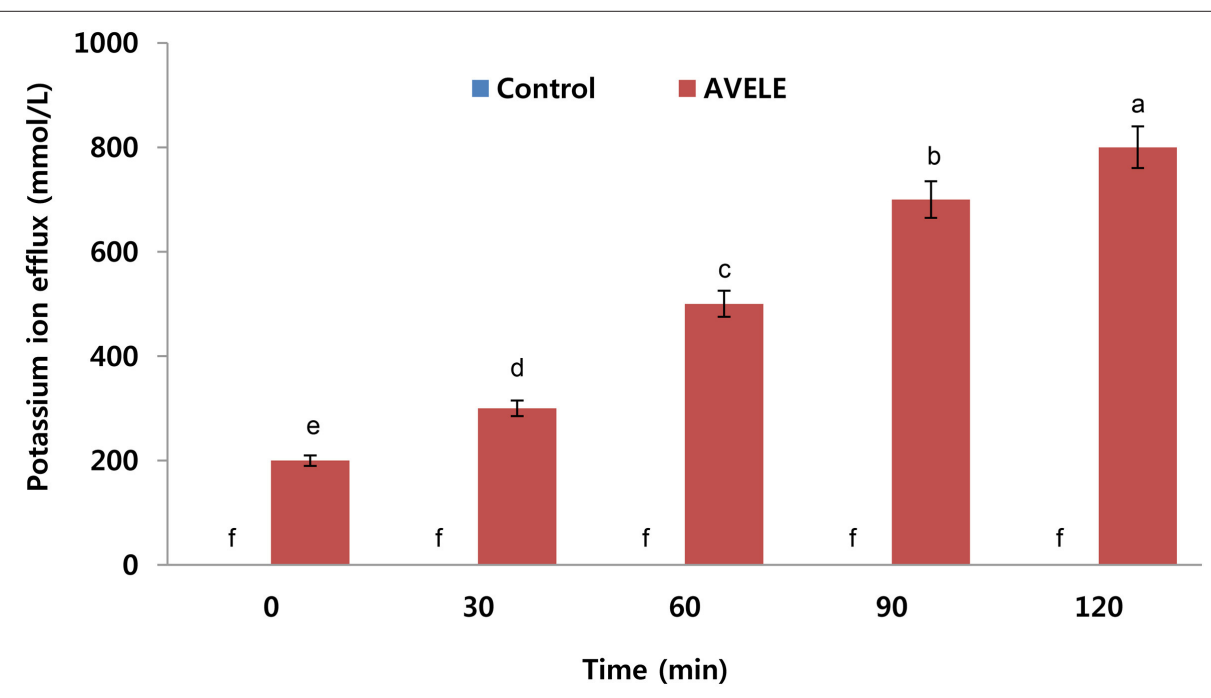

FIGURE 2 | Effects of Adhatoda vasica ethanolic leaf extract (AVELE) on the leakage of potassium ions from the cells of $L$. monocytogenes NCIM 24563. CT refers to the control without the AVELE treatment. Data expressed as the mean $\pm S D(n=3)$. The values in the same column with different superscripts are significantly different according to the Duncan's multiple range test $(p<0.05)$.

antimicrobial effects (Walden and Hentges, 1975). Figure 3 shows the effects of AVELE at its MIC on the release of 260$\mathrm{nm}$ absorbing materials from L. monocytogenes NCIM 24563. L. monocytogenes cells treated with AVELE displayed a timedependent increase in absorbance, whereas the control samples showed no remarkable change (Figures 2, 3).

As a damaged bacterial cell membrane is more permeable, small molecules, such as phosphate and potassium ions, leach out from the cells before larger molecules, such as DNA and RNA (Chen et al., 2002), which absorb strongly at $260 \mathrm{~nm}$, and are often referred to as "260-nm absorbing materials." As genetic nucleotide materials, including DNA substances absorb maximum light at $260 \mathrm{~nm}$, therefore, considering this fact, here we are measuring released DNA material from bacterial cell after treatment of AVELE extract. Furthermore, the release of these materials from bacterial cells is an indicator of a lack of membrane integrity (Bajpai et al., 2014). In the present UV-VIS study, the release of $260 \mathrm{~nm}$-absorbing materials was proportional to the AVELE concentration, whereas the control cells showed no release of these materials after $120 \mathrm{~min}$ of exposure. These results show that AVELE induced the rapid losses of 260-nm-absorbing materials from L. monocytogenes NCIM 24563, indicating irreversible damage to the cytoplasmic membrane. 


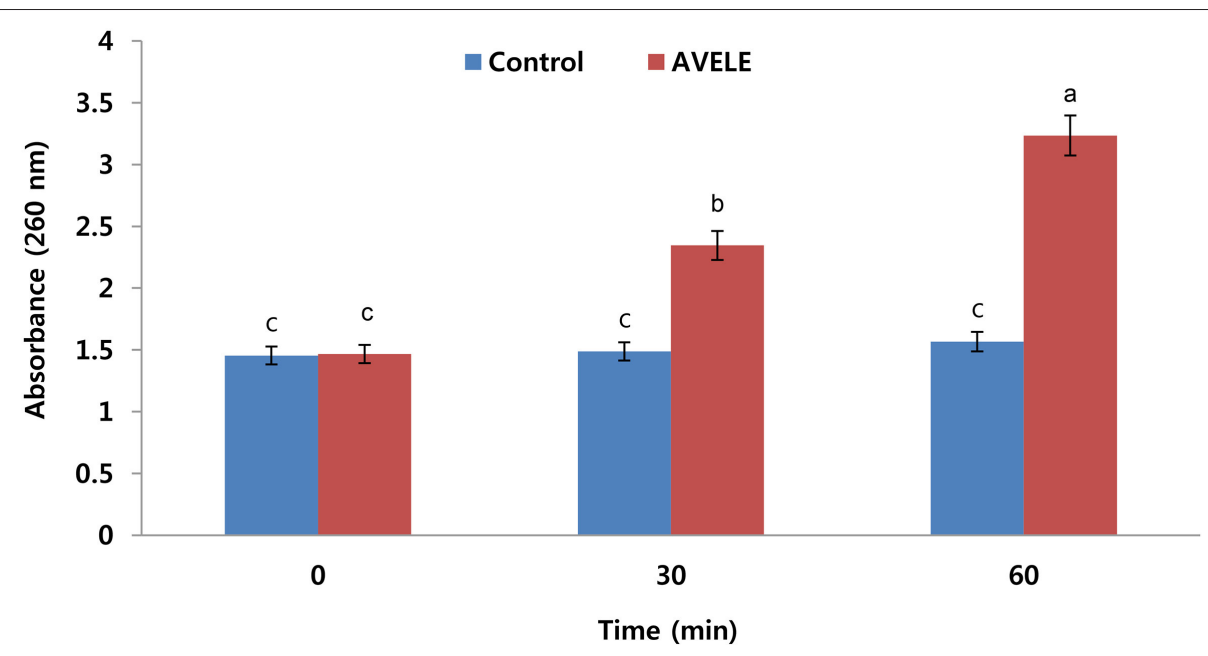

FIGURE 3 | Effect of Adhatoda vasica ethanolic leaf extract (AVELE) on the release rate of 260-nm absorbing materials from the tested foodborne pathogen, L. monocytogenes NCIM 24563. The data are expressed as the mean $\pm S D(n=3)$. The values in the same column with different superscripts are significantly different according to a Duncan's multiple range test $(p<0.05)$.

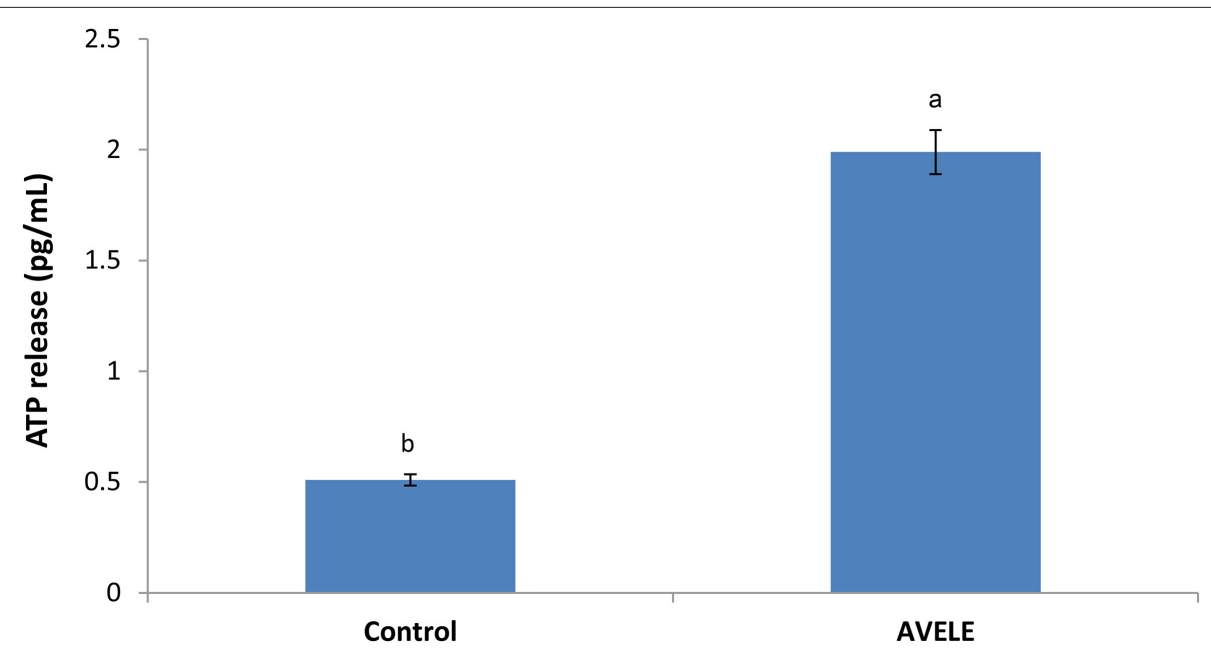

FIGURE 4 | Effect of Adhatoda vasica ethanolic leaf extract (AVELE) on the release of extracellular ATP concentration from the cells of $L$. monocytogenes NCIM 24563. Data expressed as mean $\pm S D(n=3)$. Values in the same column with different superscripts are significantly different according to Duncan's multiple range test $(p<0.05)$.

\section{Effect of AVELE on ATP Concentration}

Figure 4 shows the effects of the MIC of AVELE on the extracellular ATP concentration in the cells of $L$. monocytogenes NCIM 24563. The concentrations of extracellular ATP in the control and treated cells of L. monocytogenes NCIM 24563 were 0.51 and $1.99 \mathrm{pg} / \mathrm{mL}$, respectively. In this assay, AVELE showed a significant $(p<0.05)$ increase in the release of extracellular ATP from the target bacterial cells at the MIC when to the control group.

Previous studies have confirmed the efficacy of specific antimicrobial agents on the release of extracellular ATP loss from the target cells of foodborne pathogens, showing that antimicrobials can disrupt the bacterial cell membrane, thereby causing the loss of extracellular ATP from the target cells (Abee et al., 1994). As ATP contributes significantly to a number of cell functions, including the transportation of essential ions and metabolites across the cell-membrane, the excessive loss of ATP through a disruption of the membrane permeability might be a positive indication of the loss of cell membrane integrity, thereby causing cell death, as reported previously (Herranz et al., 2001; Bajpai et al., 2014).

\section{Application of AVELE as a Rinse for Chicken Meat Preservation and Microbial Analysis}

All weighed samples of chicken meat were enriched and plated to confirm the presence or absence of $L$. monocytogenes NCIM 
24563 prior to artificial inoculation; no prior contamination was detected. AVELE at concentrations of 50, 100, and $200 \mathrm{mg} / \mathrm{mL}$ was examined for its anti-listerial effect as a rinse on the raw chicken breast meat samples. L. monocytogenes counts were reduced significantly when the meat samples were rinsed with AVELE at $50 \mathrm{mg} / \mathrm{mL}$, but they were not eliminated completely (Table 3). On the other hand, AVELE at $200 \mathrm{mg} / \mathrm{mL}$ for $90 \mathrm{~min}$ eradicated L. monocytogenes NCIM 24563 completely. Chao and Yin (2009) also observed that a Hibiscus extract at $10 \mathrm{mg} / \mathrm{mL}$ had a far greater antimicrobial effect against foodborne pathogens than at $5 \mathrm{mg} / \mathrm{mL}$. In the current study, AVELE at concentrations of 50 and $100 \mathrm{mg} / \mathrm{ml}$ for $24 \mathrm{~h}$ could reduce the viable cell counts of L. monocytogenes (Table 3A). Higginbotham et al. (2014) also reported the anti-listerial effects of a Hibiscus rinse solution at 120 and $240 \mathrm{mg} / \mathrm{mL}$ on artificially contaminated hot dogs and found that both rinse solutions could reduce and/or eradicate the bacterial counts after a rinse treatment of $60 \mathrm{~min}$ and a storage time of $24 \mathrm{~h}$. Based on the above findings, the mechanism of the reduction of the L. monocytogenes NCIM 24563 cell count using AVELE was time-dependent; a longer treatment time of AVELE reduced the cell numbers significantly (Tables 3A,B). Another study reported the inhibitory effects of dry seasoning treatment of chicken meat products on the survival of bacterial foodborne pathogens (Perko-Mäkelä et al., 2000). Several other researchers determined the inhibitory effects of various semisolid and liquid marinades added to chicken filets and observed a significant cell count reduction of a foodborne pathogen, Campylobacter jejuni (Birk et al., 2010).

Two important aspects of the application of AVELE as a rinse are its antimicrobial effect on the meat sample and the acceptance of the treatment by the consumers. The use of naturally occurring antimicrobial agents in food system with enhanced functional properties has attracted considerable attention because these might be easily accepted by consumers. A better understanding of how bacteria cope with stress (e.g., resistance to antimicrobial compounds with different target sites in the cell, such as plant phenolic extracts), and adapt to a protective environment (e.g., chicken meat components), will be critical in the design of new (combined) intervention strategies and control methods for food safety management.

Various other rinses, such as acetylpyridinium chloride, have also been examined for their ability to inactivate harmful pathogens on ready-to-eat meat products. For example, spraying cetylpyridinium chloride at a concentration of $1 \%$ could reduce the L. monocytogenes NCIM 24563 counts on frankfurters (Singh et al., 2005). On the other hand, cetylpyridinium chloride is a synthetic compound, and despite its equivalent efficacy to those of plant extracts, such as Hibiscus extracts, it does not have the same appeal as natural products (Higginbotham et al., 2014). Similarly, Byelashov et al. (2008) reported that a combination of $5 \%$ lactic acid and $0.5 \%$ sodium lauryl sulfate applied to artificially contaminated frankfurters resulted in a significant decrease in the viable counts of L. monocytogenes NCIM 24563 after storage for 90 days.

In addition, in the present study, cell growth was analyzed for longer periods ( 36 and $48 \mathrm{~h}$ ). As a result, there were no significant differences in the cell counts of $L$. monocytogenes
NCIM 24563 and S. typhimurium ATCC 43174 contaminated food matrices after 24,36 , and $48 \mathrm{~h}$. Changes in cell counts were noted after treatment with different AVELE rinsing solutions for different exposure times, which confirms that contact with the antimicrobial rinse solution affected the reduction in cell counts of L. monocytogenes NCIM 24563 on meat samples without any further regrowth in the bacterial community. Overall, a higher extract concentration, longer rinse time, with longer storage period $(24,36$, and $48 \mathrm{~h})$ were the most effective treatments for inhibiting and/or killing L. monocytogenes NCIM 24563 on chicken meat. These findings suggest that the use of an AVELE solution at an appropriate concentration $(100 \mathrm{mg} / \mathrm{mL})$ as a rinse agent might provide a feasible means of controlling L. monocytogenes NCIM 24563 contamination without adversely affecting the sensory quality of the tested meat products.

\section{Sensory Analysis of Chicken Meat Samples}

The AVELE rinse-treated and non-treated chicken samples were cooked. After cooking, the samples were then cooled to room temperature for $1 \mathrm{~h}$ and analyzed for their color, and sensory characteristics. Table 4 lists the effects of the rinsing time and rinse concentration on the sensory properties of treated and non-treated, cooked chicken samples. At higher concentrations (200 mg/mL), although AVELE showed complete killing of the bacterial population of L. monocytogenes NCIM 24563, the flavor and taste of the resulting cooked chicken meat gave poor sensory scores. The consumers reported that it had a bitter taste with unacceptable color attributes (Table 4). Zhang et al. (2017) also reported that natural preservatives in larger amounts may alter the original food flavor in some cases, which is unacceptable to some consumers. Overall, the sensory properties were affected by the rinsing time and concentration, with almost all sensory attributes affected, including the meat tenderness, juiciness, taste, and flavor. The $\mathrm{pH}$ of the rinse solution was also reported to be 5.6-6.2, which does not have any effect on the adverse sensory and color attributes (data not shown). Based on the sensory analysis results, 5 and 10\% AVELE (50 and $100 \mathrm{mg} / \mathrm{mL}$ ) for a longer rinsing time (90 $\mathrm{min}$ ) did not have adverse effects on the sensory attributes compared to untreated chicken samples and showed better tenderness with an overall consumer acceptability score (7.4-8.3) of the rinse-treated chicken samples than the other treatment groups.

\section{Color Quality of Cooked Chicken}

The color quality of the AVELE rinse-treated chicken meat samples differed slightly in lightness $\left(\mathrm{L}^{*}\right)$, redness $\left(\mathrm{a}^{*}\right)$, and yellowness $\left(b^{*}\right)$ from the control (untreated chicken samples). The rinsing concentration and rinse time were closely related to the color change in the cooked chicken samples. The $5 \%$ and $10 \%$ AVELE (50 and $100 \mathrm{mg} / \mathrm{mL}$ ) for a rinsing time of 60 and 90 min showed a significantly low L* (lightness) value, and high $\mathrm{a}^{*}$ (redness), and yellowness values $\left(\mathrm{b}^{*}\right)$ compared to the untreated and the AVELE treatments for a 30 min rinsing time $(p<0.05)$ (Table 4), suggesting a positive correlation between the $\mathrm{L}^{*}$ (lightness) and $\mathrm{a}^{*}$ (redness) values upon the increasing chicken rinsing time. During sensory analysis, the color of the AVELE treated, cooked chicken was also one of the attributes 
TABLE 3A | Log CFU/g of Listeria monocytogenes NCIM 24563 and Salmonella typhimurium ATCC 43174 plated on agar plate following a rinse (5, 10, 15, 30, 60, and $90 \mathrm{~min}$ ) with either distilled water or Adhatoda vasica ethanolic leaf extract (AVELE) (50, 100, and $200 \mathrm{mg} / \mathrm{mL}$ ) in artificially inoculated raw chicken breast meat after $24 \mathrm{~h}$ storage at $4^{\circ} \mathrm{C}$.

\begin{tabular}{|c|c|c|c|c|c|}
\hline Bacterial strains & Rinse time (min) & Control (water) & $5 \%$ AVELE (50 mg/mL) & 10\% AVELE (100 mg/mL) & $20 \%$ AVELE $(200 \mathrm{mg} / \mathrm{mL})$ \\
\hline \multirow[t]{6}{*}{ Listeria monocytogenes NCIM 24563} & 5 & $6.5 \pm 0.30^{\mathrm{a}}$ & $6.5 \pm 0.01^{\mathrm{a}}$ & $6.1 \pm 0.34^{a}$ & $6.0 \pm 0.28^{a}$ \\
\hline & 10 & $6.52 \pm 0.25^{a}$ & $6.71 \pm 0.21^{b}$ & $6.6 \pm 0.02^{b}$ & $6.0 \pm 0.3^{a}$ \\
\hline & 15 & $6.5 \pm 0.01^{a}$ & $6.8 \pm 0.01^{b}$ & $6.2 \pm 0.03^{C}$ & $5.1 \pm 0.32^{b}$ \\
\hline & 30 & $6.55 \pm 0.02^{\mathrm{a}}$ & $4.8 \pm 0.04^{c}$ & $4.5 \pm 0.12^{d}$ & $3.7 \pm 0.10^{c}$ \\
\hline & 60 & $6.6 \pm 0.30^{b}$ & $4.2 \pm 0.3^{d}$ & $3.6 \pm 0.06^{\mathrm{e}}$ & $2.2 \pm 0.21^{d}$ \\
\hline & 90 & $6.6 \pm 0.21^{b}$ & $3.3 \pm 0.22^{e}$ & $2.0 \pm 0.12^{f}$ & ND \\
\hline \multirow[t]{6}{*}{ Salmonella typhimurium ATCC 43174} & 5 & $6.8 \pm 0.14^{a}$ & $6.5 \pm 0.11^{a}$ & $6.5 \pm 0.02^{a}$ & $6.5 \pm 0.21^{a}$ \\
\hline & 10 & $6.7 \pm 0.03^{a}$ & $6.38 \pm 0.32^{a}$ & $6.36 \pm 0.02^{a}$ & $6.44 \pm 0.16^{a}$ \\
\hline & 15 & $6.6 \pm 0.01^{b}$ & $6.0 \pm 0.06^{b}$ & $5.6 \pm 0.13^{b}$ & $5.1 \pm 0.08^{b}$ \\
\hline & 30 & $6.6 \pm 0.21^{a}$ & $5.7 \pm 0.43^{c}$ & $5.41 \pm 0.06^{b}$ & $5.0 \pm 0.02^{b}$ \\
\hline & 60 & $6.6 \pm 0.03^{a}$ & $5.5 \pm 0.11^{c}$ & $5.32 \pm 0.02^{b}$ & $4.4 \pm 0.17^{c}$ \\
\hline & 90 & $6.57 \pm 0.11^{b}$ & $5.4 \pm 0.18^{c}$ & $5.30 \pm 0.01^{b}$ & $4.0 \pm 0.12^{d}$ \\
\hline
\end{tabular}

$N D$, Colonies not detected. Values in the same column with different superscripts are significantly different according to Duncan's multiple range test ( $p<0.05)$.

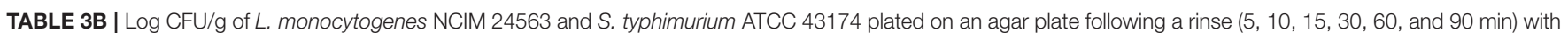
either water or A. vasica ethanolic leaf extract (AVELE) $\left(50,100\right.$, and $200 \mathrm{mg} / \mathrm{mL}$ ) in artificially inoculated pork meat and ready-to eat-salad after $24 \mathrm{~h}$ storage at $4{ }^{\circ} \mathrm{C}$.

\begin{tabular}{|c|c|c|c|c|c|}
\hline Bacterial strains & Rinse time (min) & Control (water) & $5 \%$ AVELE (50 mg/mL) & 10\% AVELE (100 mg/mL) & $20 \%$ AVELE $(200 \mathrm{mg} / \mathrm{mL})$ \\
\hline \multicolumn{6}{|c|}{ ARTIFICIALLY INOCULATED PORK MEAT } \\
\hline \multirow[t]{6}{*}{ Listeria monocytogenes NCIM 24563} & 5 & $6.0 \pm 0.01^{a}$ & $6.2 \pm 0.01^{a}$ & $6.2 \pm 0.34^{\mathrm{a}}$ & $6.0 \pm 0.11^{\mathrm{a}}$ \\
\hline & 10 & $6.2 \pm 0.22^{a}$ & $6.6 \pm 0.31^{b}$ & $6.4 \pm 0.42^{b}$ & $5.0 \pm 0.23^{b}$ \\
\hline & 15 & $6.2 \pm 0.11^{a}$ & $6.6 \pm 0.00^{b}$ & $6.7 \pm 0.13^{c}$ & $4.4 \pm 0.43^{\mathrm{C}}$ \\
\hline & 30 & $6.57 \pm 0.32^{b}$ & $5.6 \pm 0.16^{c}$ & $4.0 \pm 0.22^{d}$ & $3.5 \pm 0.00^{d}$ \\
\hline & 60 & $6.6 \pm 0.10^{b}$ & $4.5 \pm 0.3^{d}$ & $3.2 \pm 0.43^{\mathrm{e}}$ & $2.8 \pm 0.01^{e}$ \\
\hline & 90 & $6.5 \pm 0.22^{\mathrm{C}}$ & $4.0 \pm 0.12^{e}$ & $1.6 \pm 0.42^{f}$ & ND \\
\hline \multirow[t]{6}{*}{ Salmonella typhimurium ATCC 43174} & 5 & $6.8 \pm 0.14^{\mathrm{a}}$ & $6.5 \pm 0.10^{\mathrm{a}}$ & $6.5 \pm 0.02^{\mathrm{a}}$ & $6.5 \pm 0.21^{a}$ \\
\hline & 10 & $6.7 \pm 0.43^{a}$ & $6.68 \pm 0.12^{a}$ & $6.36 \pm 0.02^{a}$ & $6.44 \pm 0.16^{a}$ \\
\hline & 15 & $6.6 \pm 0.21^{b}$ & $5.8 \pm 0.16^{b}$ & $5.6 \pm 0.13^{b}$ & $5.1 \pm 0.08^{b}$ \\
\hline & 30 & $6.6 \pm 0.21^{b}$ & $5.7 \pm 0.22^{\mathrm{C}}$ & $5.41 \pm 0.06^{b}$ & $5.0 \pm 0.02^{b}$ \\
\hline & 60 & $6.5 \pm 0.23^{b}$ & $5.6 \pm 0.21^{c}$ & $5.32 \pm 0.02^{b}$ & $5.0 \pm 0.17^{b}$ \\
\hline & 90 & $6.63 \pm 0.41^{b}$ & $5.0 \pm 0.12^{d}$ & $5.30 \pm 0.01^{b}$ & $4.6 \pm 0.12^{c}$ \\
\hline \multicolumn{6}{|l|}{ READY-TO-EAT FRESH CUT SALAD } \\
\hline \multirow[t]{6}{*}{ Listeria monocytogenes NCIM 24563} & 5 & $6.0 \pm 0.01^{a}$ & $6.0 \pm 0.11^{\mathrm{a}}$ & $6.2 \pm 0.20^{\mathrm{a}}$ & $6.0 \pm 0.51^{\mathrm{a}}$ \\
\hline & 10 & $6.2 \pm 0.22^{a}$ & $6.2 \pm 0.21^{a}$ & $6.2 \pm 0.11^{\mathrm{a}}$ & $6.0 \pm 0.63^{a}$ \\
\hline & 15 & $6.2 \pm 0.11^{a}$ & $6.21 \pm 0.03^{a}$ & $6.5 \pm 0.64^{b}$ & $6.2 \pm 0.44^{a}$ \\
\hline & 30 & $6.57 \pm 0.32^{b}$ & $6.0 \pm 0.38^{b}$ & $6.0 \pm 0.51^{c}$ & $6.0 \pm 0.71^{\mathrm{a}}$ \\
\hline & 60 & $6.6 \pm 0.10^{b}$ & $5.5 \pm 0.04^{c}$ & $5.8 \pm 0.54^{c}$ & $5.5 \pm 0.21^{b}$ \\
\hline & 90 & $6.5 \pm 0.22^{\mathrm{C}}$ & $5.5 \pm 0.03^{c}$ & $5.5 \pm 0.63^{d}$ & $5.3 \pm 0.04^{b}$ \\
\hline \multirow[t]{6}{*}{ Salmonella typhimurium ATCC 43174} & 5 & $6.8 \pm 0.14^{a}$ & $6.3 \pm 0.10^{a}$ & $6.6 \pm 0.11^{a}$ & $6.2 \pm 0.33^{a}$ \\
\hline & 10 & $6.7 \pm 0.43^{a}$ & $6.4 \pm 0.12^{\mathrm{a}}$ & $6.6 \pm 0.48^{a}$ & $6.0 \pm 0.06^{a}$ \\
\hline & 15 & $6.6 \pm 0.21^{b}$ & $6.8 \pm 0.16^{b}$ & $6.0 \pm 0.06^{b}$ & $5.6 \pm 0.18^{b}$ \\
\hline & 30 & $6.6 \pm 0.21^{b}$ & $6.5 \pm 0.22^{c}$ & $5.71 \pm 0.14^{\mathrm{C}}$ & $5.5 \pm 0.64^{b}$ \\
\hline & 60 & $6.5 \pm 0.23^{b}$ & $6.3 \pm 0.21^{c}$ & $5.6 \pm 0.23^{c}$ & $5.2 \pm 0.45^{c}$ \\
\hline & 90 & $6.63 \pm 0.41^{b}$ & $6.0 \pm 0.12^{d}$ & $5.6 \pm 0.11^{c}$ & $5.1 \pm 0.07^{c}$ \\
\hline
\end{tabular}

$N D$, Colonies not detected. Values in the same column with different superscripts are significantly different according to Duncan's multiple range test ( $p<0.05)$.

for its consumer acceptability. In the present study, a higher concentration of AVELE rinse solution (20\%) showed significant differences in color values than the other concentrations of
AVELE and non-treated chicken samples, which could not meet the consumer acceptability criteria due to the appearance of chicken meat samples during the sensory evaluation. Yusop et al. 
TABLE 4 | Sensory evaluation and Hunter's color value of an AVELE rinse solution treated, cooked chicken meat for overall consumers acceptability point view.

\begin{tabular}{|c|c|c|c|c|c|c|c|c|c|c|}
\hline \multirow[t]{2}{*}{ Rinse type } & \multirow[t]{2}{*}{ Rinse time } & \multirow[t]{2}{*}{ Taste } & \multirow[t]{2}{*}{ Odor } & \multirow[t]{2}{*}{ Flavor } & \multirow[t]{2}{*}{ Tenderness } & \multirow[t]{2}{*}{ Color } & \multirow{2}{*}{$\begin{array}{c}\text { Overall } \\
\text { acceptability }\end{array}$} & \multicolumn{3}{|c|}{ Hunter's color values } \\
\hline & & & & & & & & $\mathbf{L}^{*}$ & $a^{*}$ & $\mathbf{b}^{*}$ \\
\hline Control & - & $7.2 \pm 0.14$ & $8.4 \pm 0.05$ & $8.1 \pm 1.22$ & $5.0 \pm 1.1$ & $7.8 \pm 1.21$ & $8.2 \pm 0.41$ & $67.6 \pm 1.43$ & $25.4 \pm 3.76$ & $13.8 \pm 6.65$ \\
\hline \multirow[t]{6}{*}{$\mathrm{R}_{1}(50 \mathrm{mg} / \mathrm{mL})$} & 5 & $7.0 \pm 0.34$ & $8.2 \pm 1.2$ & $7.8 \pm 0.18$ & $5.0 \pm 1.22$ & $7.0 \pm 0.81$ & $7.4 \pm 0.08$ & $67.2 \pm 5.78$ & $24.4 \pm 7.22$ & $15.1 \pm 7.55$ \\
\hline & 10 & $6.6 \pm 0.14$ & $7.4 \pm 0.76$ & $7.4 \pm 0.21$ & $5.5 \pm 0.23$ & $7.4 \pm 0.16$ & $7.0 \pm 0.13$ & $65.6 \pm 4.09$ & $25.0 \pm 4.81$ & $15.5 \pm 7.59$ \\
\hline & 15 & $6.7 \pm 0.4$ & $8.0 \pm 0.88$ & $7.3 \pm 0.11$ & $5.8 \pm 0.11$ & $7.7 \pm 0.72$ & $7.3 \pm 0.22$ & $64.0 \pm 4.18$ & $25.7 \pm 5.13$ & $15.8 \pm 7.98$ \\
\hline & 30 & $6.6 \pm 0.33$ & $7.8 \pm 0.24$ & $7.5 \pm 0.12$ & $6.2 \pm 0.31$ & $7.8 \pm 0.54$ & $7.6 \pm 0.12$ & $64.5 \pm 7.12$ & $26.8 \pm 5.14$ & $15.7 \pm 6.00$ \\
\hline & 60 & $6.8 \pm 0.10$ & $8.4 \pm 0.31$ & $7.8 \pm 1.18$ & $6.0 \pm 0.83$ & $7.8 \pm 0.21$ & $8.0 \pm 0.10$ & $63.0 \pm 4.12$ & $27.3 \pm 5.03$ & $15.6 \pm 6.90$ \\
\hline & 90 & $6.7 \pm 0.40$ & $8.2 \pm 0.33$ & $7.4 \pm 1.6$ & $6.4 \pm 0.44$ & $7.8 \pm 0.11$ & $7.9 \pm 0.18$ & $62.7 \pm 3.56$ & $27.8 \pm 6.19$ & $15.8 \pm 6.44$ \\
\hline \multirow[t]{6}{*}{$\mathrm{R}_{2}(100 \mathrm{mg} / \mathrm{mL})$} & 5 & $6.6 \pm 0.21$ & $7.8 \pm 0.61$ & $7.8 \pm 0.03$ & $6.3 \pm 0.32$ & $7.0 \pm 0.52$ & $7.7 \pm 0.16$ & $62.5 \pm 7.22$ & $25.4 \pm 4.99$ & $14.2 \pm 4.86$ \\
\hline & 10 & $6.5 \pm 0.17$ & $7.7 \pm 0.55$ & $7.8 \pm 0.13$ & $8.0 \pm 0.36$ & $7.0 \pm 0.61$ & $8.0 \pm 0.18$ & $62.9 \pm 5.84$ & $26.3 \pm 7.26$ & $14.8 \pm 4.85$ \\
\hline & 15 & $6.8 \pm 1.10$ & $8.0 \pm 0.12$ & $7.7 \pm 0.32$ & $8.2 \pm 0.04$ & $7.5 \pm 0.13$ & $8.0 \pm 0.21$ & $63.0 \pm 5.87$ & $27.0 \pm 4.96$ & $15.4 \pm 4.74$ \\
\hline & 30 & $6.7 \pm 0.02$ & $8.0 \pm 0.31$ & $8.0 \pm 0.41$ & $8.2 \pm 0.31$ & $7.7 \pm 0.17$ & $8.2 \pm 0.18$ & $63.3 \pm 8.34$ & $27.7 \pm 4.61$ & $15.8 \pm 5.56$ \\
\hline & 60 & $7.0 \pm 1.1$ & $8.6 \pm 0.11$ & $8.0 \pm 0.55$ & $8.3 \pm 0.51$ & $8.0 \pm 0.10$ & $8.3 \pm 0.20$ & $63.1 \pm 2.21$ & $28.5 \pm 5.18$ & $15.2 \pm 3.45$ \\
\hline & 90 & $6.8 \pm 0.8$ & $7.0 \pm 0.12$ & $7.4 \pm 1.14$ & $8.4 \pm 0.63$ & $7.6 \pm 1.10$ & $7.0 \pm 1.16$ & $61.3 \pm 6.43$ & $26.1 \pm 4.96$ & $15.0 \pm 3.75$ \\
\hline \multirow[t]{6}{*}{$\mathrm{R}_{3}(100 \mathrm{mg} / \mathrm{mL})$} & 5 & $5.1 \pm 0.45$ & $5.2 \pm 0.41$ & $5.0 \pm 0.17$ & $7.8 \pm 0.21$ & $7.2 \pm 0.21$ & $6.4 \pm 0.81$ & $61.0 \pm 6.98$ & $26.1 \pm 4.89$ & $15.4 \pm 5.15$ \\
\hline & 10 & $5.0 \pm 0.34$ & $5.0 \pm 0.18$ & $4.5 \pm 0.35$ & $6.6 \pm 0.33$ & $5.6 \pm 0.41$ & $5.7 \pm 0.92$ & $56.5 \pm 4.67$ & $27.3 \pm 4.97$ & $15.9 \pm 4.60$ \\
\hline & 15 & $5.0 \pm 0.11$ & $5.2 \pm 0.19$ & $4.8 \pm 0.41$ & $6.6 \pm 0.12$ & $5.7 \pm 0.52$ & $5.0 \pm 0.23$ & $53.2 \pm 5.06$ & $27.7 \pm 6.55$ & $16.3 \pm 4.65$ \\
\hline & 30 & $5.8 \pm 0.31$ & $4.4 \pm 0.20$ & $4.5 \pm 1.14$ & $7.4 \pm 0.22$ & $5.0 \pm 0.61$ & $5.5 \pm 0.31$ & $51.7 \pm 4.44$ & $28.1 \pm 7.21$ & $16.6 \pm 5.11$ \\
\hline & 60 & $5.0 \pm 0.42$ & $4.2 \pm 0.16$ & $4.7 \pm 0.43$ & $7.4 \pm 0.18$ & $5.6 \pm 1.82$ & $5.2 \pm 0.62$ & $50.3 \pm 4.81$ & $28.6 \pm 6.32$ & $16.8 \pm 5.13$ \\
\hline & 90 & $5.5 \pm 0.13$ & $3.6 \pm 0.21$ & $3.9 \pm 1.13$ & $7.8 \pm 0.81$ & $4.5 \pm 1.18$ & $5.0 \pm 0.13$ & $48.5 \pm 4.66$ & $28.9 \pm 6.98$ & $17.4 \pm 4.96$ \\
\hline
\end{tabular}

The experiments were performed in triplicate and values are presented as the mean $\pm S D$.

(2010) also reported that prolonged marinating or rinsing times using Chinese-style marinades and rinse solutions had significant effects in producing a product with lower $\mathrm{L}^{*}$ (lightness) and higher a* (redness) values.

\section{Effects of AVELE Rinse Solution on Other Food Matrices Contaminated with L. monocytogenes NCIM 24563 and S. typhimurium ATCC 43174}

In this study, AVELE was more active in eradicating L. monocytogenes NCIM 24563 than S. typhimurium ATCC 43174 when the chicken samples were treated with the AVELE rinse solutions (50, 100, and $200 \mathrm{mg} / \mathrm{mL}$ ). Surprisingly, in preliminary studies, AVELE could reduce the $S$. typhimurium ATCC 43174 counts in pure cultures but during its applicability as a rinse on chicken meat, it did not show a significant reduction in the cell counts of $S$. typhimurium ATCC 43174 except for a very minor cell count reduction, suggesting that there might be some interference due to the components of chicken meat food matrices, such as proteins or fats (Table 3A). Similarly, Friedman et al. (2017) reported that plant extracts rich in phytochemicals had inhibitory potential against E. coli O157:H7 but not against Salmonella enterica in an essential oil/wine mixture, suggesting some synergistic effects of the phytochemicals present in plant extracts, components of added essential oils or natively present in the food wine (Rota et al., 2008).
In addition, the colony counts, even after the addition of AVELE to the meat samples, showed a similar or higher level of contamination over a few minutes, which were reduced gradually (Tables 3A,B). This is called the phoenix effect, where a few microbial cells survive for a long lag phase and then begin to regrow. A similar reduction rate in the microbial counts has been observed in many food products (Subramaniam et al., 2015).

This study tested the efficacy of AVELE as a rinse with few other food matrices, including pork meat and ready-to-eat fresh cut salad against L. monocytogenes NCIM 24563 and S. typhimurium ATCC 43174. A significant decrease in the cell counts of L. monocytogenes NCIM 24563 and S. typhimurium ATCC 43174 compared to the control (without treatment) was observed. A comparison of the rinsing effect of AVELE with different food matrices revealed a strong reduction in the cell counts in the case of only chicken and pork meat samples contaminated with NCIM 24563 than S. typhimurium ATCC 43174 in all food matrices (Table 3B). AVELE, as a rinse, had no reducing effect on the bacterial counts of $L$. monocytogenes NCIM 24563 and Salmonella ATCC 43174 in ready-to-eat fresh cut salad. This might have occurred due to the variations in the composition of the different food matrices, such as chicken and pork meat, which are similarly rich in protein and fat, compared to the ready-to-eat fresh cut salad. This highlights the applicability of AVELE as a rinse in a variety of food matrices contaminated with different foodborne pathogenic microflora, particularly L. monocytogenes. 


\section{CONCLUSION}

The ethanolic leaf extract of A. vasica (AVELE) showed significant antibacterial activity, as evidenced by its inhibitory effects on bacterial growth, cell viability, potassium ion efflux, release of $260-\mathrm{nm}$ absorbing materials, and loss of the extracellular ATP pool. Moreover, a AVELE solution as a rinse/marinade effectively decreased the bacterial counts of L. monocytogenes inoculated into raw and processed minced chicken meat samples; this was attributed tentatively to its phenolic, flavonoid, and alkaloid contents. Furthermore, AVELE, as a rinse, could enhance the nutritional value of meat products, as confirmed by the sensory scores with improved tenderness, juiciness, and flavor of the meat samples. These findings reinforce the suggestions that AVELE improved the safety and quality of ready-to-eat and raw meat products by inhibiting

\section{REFERENCES}

Abee, T., Klaenhammer, T. R., and Letellier, L. (1994). Kinetic studies of the action of lactacin F, a bacteriocin produced by Lactobacillus johnsonii that forms poration complexes in the cytoplasmic membrane. Appl. Environ. Microbiol. 60, 1006-1013.

Ahmad, F., and Tabassum, N. (2013). Effect of 70\% ethanolic extract of roots of Paeonia officinalis Linn. On hepatotoxicity. J. Acute Med. 3, 45-49. doi: 10.1016/j.jacme.2013.04.001

Appendini, P., and Hotchkiss, J. H. (2002). Review of antimicrobial food packaging. Innov. Food Sci. Emerg. Technol. 3, 113-126. doi: 10.1016/S1466-8564(02)00012-7

Aureli, P., Fiorucci, G. C., Caroli, D., Marchiaro, G., Novara, O., Leone, L., et al. (2000). An outbreak of febrile gastroenteritis associated with corn contaminated by Listeria monocytogenes. N. Eng. J. Med. 342, 1236-1241. doi: 10.1056/NEJM200004273421702

Bajpai, V. K., Sharma, A., Bokyung, M., and Baek, K. H. (2014). Chemical composition analysis and antibacterial mode of action of Taxus Cuspidata leaf essential oil against foodborne pathogens. J. Food Saf. 34, 9-20. doi: $10.1111 /$ jfs. 12089

Bakkali, F., Averbeck, S., Averbeck, D., and Idaomar, M. (2008). Biological effects of essential oils-a review. Food Chem. Toxicol. 46, 446-475. doi: 10.1016/j.fct.2007.09.106

Benbott, A., Yahyia, A., and Belaidi, A. (2012). Assessment of the antibacterial activity of crude alkaloids extracted from seeds and roots of the plant Peganum harmala L. J. Nat. Prod. Plant Resour. 2, 568-573.

Birk, T., Gronlund, A. C., Christensen, B. B., Knochel, S., Lohse, K., and Rosenquist, H. (2010). Effect of organic acids and marination ingredients on the survival of Campylobacter jejuni on meat. J. Food Prot. 73, 258-265. doi: 10.4315/0362-028X-73.2.258

Bravo, L. (1998). Polyphenols: chemistry, dietary sources, metabolism, and nutritional significance. Nutr. Rev. 56, 317-333. doi: 10.1111/j.1753-4887.1998.tb01670.x

Byelashov, O. A., Kendall, P. A., Belk, K. E., Scanga, J. A., and Sofos, J. N. (2008). Control of Listeria monocytogenes on vacuum-packaged frankfurters sprayed with lactic acid alone or in combination with sodium lauryl sulfate. J. Food Prot. 71, 728-734. doi: 10.4315/0362-028X-71. 4.728

Byun, S. M., No, H. K., Hong, J. H., Lee, S. I., and Prinyawiwatkul, W. (2013). Comparison of physicochemical, binding, antioxidant and antibacterial properties of chitosans prepared from ground and entire crab leg shells. Int. J. Food Sci. Technol. 48, 136-142. doi: 10.1111/j.1365-2621.2012.03169.x

CDC-Centers for Disease Control and Prevention (2014). Multistate Outbreak of Listeriosis Linked to Roos Foods Dairy Products. Available online at: http://www.cdc.gov/listeria/outbreaks/cheese-02-14/ (Accessed July 17, 2014).
L. monocytogenes, and can be recommended as a rinse or marinade for future applications in the food industry with enhanced consumer acceptability.

\section{AUTHOR CONTRIBUTIONS}

SS, LA, and VB performed experiments and wrote the manuscript; YSH and YKH: designed the experimental strategy, and critically reviewed the manuscript.

\section{ACKNOWLEDGMENTS}

The authors are grateful for the Basic Science Research Program through the National Research Foundation of Korea (NRF) funded by the Ministry of Science, ICT \& Future Planning (2016R1A2B4013374 \& 2014R1A5A1009799).
Carson, C. F., Mee, B. J., and Riley, T. V. (2002). Mechanism of action of tea tree oil on Staphylococcus aureus determined by timen-kill, lysis, leakage, and salt tolerance assays and electron microscopy. Antimicrob. Agents Chemother. 6, 1914-1920. doi: 10.1128/A.A.C.46.6.1914-1920.2002

Chao, C. Y., and Yin, M. C. (2009). Antibacterial effects of Roselle calyx extracts and protocatechuic acid in ground beef and apple juice. Foodborne Pathogens Dis. 6, 201-206. doi: 10.1089/fpd.2008.0187

Chen, X., Schauder, S., Potier, N., Van Dorsselaer, A., Pelczer, I., Bassler, B. L., et al. (2002). Structural identification of a bacterial quorum-sensing signal containing boron. Nature 415, 545-549. doi: 10.1038/415545a

Claeson, U. P., Malmfors, T., Wikman, G., and Bruhn, J. G. (2000). Adhatoda vasica: a critical review of ethnopharmacological and toxicological data. J. Ethanopharmacol. 72, 1-20. doi: 10.1016/S0378-8741(00)00225-7

Corbo, M. R., Speranza, B., Filippone, A., Granatiero, S., Conte, A., Sinigaglia, M., et al. (2008). Study on the synergic effect of natural compounds on the microbial quality decay of packed fish hamburger. Int. J. Food Microbiol. 127, 261-267. doi: 10.1016/j.ijfoodmicro.2008.07.014

Cox, S. D., Mann, C. M., Markhan, J. L., Gustafson, J. E., Warmington, J. R., and Wyllie, S. G. (2001). Determining the antimicrobial action of tea tree oil. Molecules 6, 87-91. doi: 10.3390/60100087

Dussault, D., Vu, K. D., Vansach, T., Horgen, F. D., and Lacroix, M. (2016). Antimicrobial effects of marine algal extracts and cyanobacterial pure compounds against five foodborne pathogens. Food Chem. 199, 114-118. doi: 10.1016/j.foodchem.2015.11.119

Friedman, M., Levin, C. E., and Henika, P. R. (2017). Addition of phytochemicalrich plant extracts mitigate the antimicrobial activity of essential oil/wine mixtures against Escherichia coli O157:H7 but not against Salmonella enterica. Food Control 73, 562-565. doi: 10.1016/j.foodcont.2016.09.002

Goulet, V., Hedberg, C., Le Monnier, A., and De Valk, H. (2008). Increasing incidence of listeriosis in Frrnace and other European countries. Emerg. Infect. Dis. 14, 734-740. doi: 10.3201/eid1405.071395

Herranz, C., Chen, Y., Chung, H. J., Cintas, L. M., Hernandez, P. E., Montville, T. J., et al. (2001). Enterocin P selectively dissipates the membrane potential of Enterococcus faecium T136. Appl. Environ. Microbiol. 67, 1689-1692. doi: 10.1128/AEM.67.4.1689-1692.2001

Higginbotham, K. L., Burris, K. P., Zivanovic, S., Davidson, P. M., and Stewart, C. N. (2014). Aqueous extracts of Hibiscus sabdariffa calyces as an antimicrobial rinse on hot dogs against Listeria monocytogenes and methicillin-resistant Staphylococcus aureus. Food Control 40, 274-277. doi: 10.1016/j.foodcont.2013.12.011

Holley, R. A., and Patel, D. (2005). Improvement in shelf-life and safety of perishable foods by plant essential oils and smoke antimicrobials. Food Microbiol. 22, 273-292. doi: 10.1016/j.fm.2004.08.006

Iturraga, L., Olabarrieta, I., and De Maranon, I. M. (2012). Antimicrobial assays of natural extracts and their inhibitory effect against Listeria innocua and fish 
spoilage bacteria, after incorporation into biopolymer edible films. Int. J. Food Microbiol. 158, 58-64. doi: 10.1016/j.ijfoodmicro.2012.07.001

Kaur, I., Chauhan, P. K., Jaryal, M., Saxena, S., and Kanisha. (2012). Antioxidant and antimicrobial activity of leaf extract of Adhatoda vasica against the bacteria isolated from the sputum samples of asthmatic patients. Int. J. Drug Res. Technol. 2, 273-278.

Koleva, I. I., van Beek, T. A., Soffers, A. E. M. F., Dusemund, B., and Rietjens, I. M. C. M. (2012). Alkaloids in the human food chain - Natural occurrence and possible adverse effects. Mol. Nutr. Food Res. 56, 30-52. doi: 10.1002/mnfr.201100165

Maatalah, M. B., Bouzidi, N. K., Bellahouel, S., Merah, B., Fortas, Z., and Soulimani, R. (2012). Antimicrobial activity of the alkaloids and saponin extracts of Anabasis articulate. E3 J. Biotechnol. Pharm. Res. 3, 54-57.

Marta, G. L., Javier, R., Irma, C. B., Cristina, C., Dolores, A., and María, R. G. A. (2012). Evaluation of antimicrobial and antioxidant activities of natural phenolic compounds against foodborne pathogens and spoilage bacteria. Food Control 26, 555-563. doi: 10.1016/j.foodcont.2012.02.025

Maurya, S., and Singh, D. (2010). Quantitative analysis of total phenolic content in Adhatoda vasica Nees extracts. Int. J. PharmTech Res. 2, 2403-2406.

McLauchlin, J., Mitchell, R. T., Smerdon, W. J., and Jewell, K. (2004). Listeria monocytogenes and listeriosis: a review of hazard characterisation for use in microbiological risk assessment of foods. Int. J. Food Microbiol. 92, 15-33. doi: 10.1016/S0168-1605(03)00326-X

Meignanalakshmi, S., Vinoth Kumar, S., Deepika, J., and Farida Begum, I. (2013). Evaluation of antibacterial activity of methanol extract of leaves of Adhatoda vasica on mastitis pathogens. Hygela J. Drugs Med. 5, 1-4.

Mugisha, M. K., Ndukui, J. G., Namutembi, A., Waako, P., Karlson, A. B., and Vudriko, P. (2014). Acute and sub-acute toxicity of ethanolic leaf extracts of Rumex abyssinica Jacq. (Polygonaceae) and Mentha spicata L. (Lamiaceae). Pharmacol. Pharm. 5, 309-318.

Naczk, M., and Shahidi, F. (2004). Extraction and analysis of phenolics in food. J. Chromatogr. A 1054, 95-111. doi: 10.1016/S0021-9673(04)01409-8

Nithya, T. G., Jayanthi, J., and Ragunathan, M. G. (2016). Antioxidant activity, total phenol, flavonoid, alkaloid, tannin, and saponin contents of leaf extracts of Salvinia molesta D. S. Mitchell (1972). Asian J. Pharm. Clin. Res. 9, 200-203.

Perko-Mäkelä, P., Koljonen, M., Miettinen, M., and Hänninen, M. L. (2000). Survival of Campylobacter jejuni in marinated and non-marinated chicken products. J. Food Saf. 20, 209-216. doi: 10.1111/j.1745-4565.2000.tb00299.x

Piskernik, S., Klancnik, A., Riedel, C. T., Brøndsted, L., and Mozina, S. S. (2011). Reduction of Campylobacter jejuni by natural antimicrobials in chicken meat-related conditions. Food Control 22, 718-724. doi: 10.1016/j.foodcont.2010.11.002

Rota, M. C., Herrera, A., Martínez, R. M., Sotomayor, J. A., and Jordán, M. J. (2008). Antimicrobial activity and chemical composition of Thymus vulgaris Thymus zygis and Thymus hyemalis essential oils. Food Control 19, 681-687 doi: 10.1016/j.foodcont.2007.07.007

Sakanaka, S., Tachibana, Y., and Okada, Y. (2005). Preparation and antioxidant properties of extracts of Japanese persimmon tea (Kakinoha-cha). Food Chem. 89, 569-575. doi: 10.1016/j.foodchem.2004.03.013

Schlech, W. F., Lavigne, P. M., and Bortolussi, R. A. (1983). Epidemic listeriosis-Evidence for transmission by foods. N. Eng. J. Med. 308, 203-206. doi: 10.1056/NEJM198301273080407

Shamsa, F., Rezamonsef, H., Lahghamooshi, R., and Rezaverdian-rizi, M. (2008). Spectrophotometric determination of total alkaloids in some Iranian medicinal plants. Thai J. Pharm. Sci. 32, 17-20.

Shen, X., Sun, X., Xie, Q., and Wu, V. C. H. (2014). Antimicrobial effect of blueberry (Vaccinium corymbosum L.) extracts against the growth of
Listeria monocytogenes and Salmonella Enteritidis. Food Control 35, 159-165. doi: 10.1016/j.foodcont.2013.06.040

Shin, S. Y., Bajpai, V. K., Kim, H. R., and Kang, S. C. (2007). Antibacterial activity of bioconverted eicosapentaenoic (EPA) and docosahexaenoic acid (DHA) against foodborne pathogenic bacteria. Int. J. Food Microbiol. 113, 233-236. doi: 10.1016/j.ijfoodmicro.2006.05.020

Shiu, W. K. P., and Gibbons, S. (2006). Anti-staphylococcal acylphloroglucinols from Hypericum beanie. Phytochemistry 67, 2568-2572. doi: 10.1016/j.phytochem.2006.09.037

Singh, M., Gill, V. S., Thippareddi, H., Phebus, R. K., Marsden, J. L., and Herald, T. J. (2005). Antimicrobial activity of cetylpyridinium chloride against Listeria monocytogenes on frankfurters and subsequent effect on quality attributes. $J$. Food Prot. 68, 1823-1830. doi: 10.4315/0362-028X-68.9.1823

Singleton, V. L., Orthofer, R., and Lamuela-Raventos, R. M. (1999). "Analysis of total phenols and other oxidation substrates and antioxidants by means of Folin-Ciocalteu reagent. Methods Enzymol. 299, 152-178. doi: 10.1016/s0076-6879(99)99017-1

Stevenson, D. E., and Hurst, R. D. (2007). Polyphenolic phytochemicals just antioxidants or much more? Cell. Mol. Life Sci. 64, 2900-2916. doi: 10.1007/s00018-007-7237-1

Stone, H., and Sidel, J. L. (1985). Sensory Evaluation Practices. 1st Edn. London: Academic Press, 202-220.

Subramaniam, S., Rajendran, R., Muralidharan, S., Subramaniam, G., Rajuab, R., and Sivasubramanian, A. (2015). Dual role of select plant based nutraceuticals as antimicrobial agents to mitigate food borne pathogens and as food preservatives. RSC Adv. 5, 77168. doi: 10.1039/C5RA15039F

Takahashi, H., Takahashi, T., Miya, S., Yokoyama, H., Kuda, T., and Kimura, B. (2015). Growth inhibition effects of ferulic acid and glycine/sodium acetate on Listeria monocytogenes in coleslaw and egg salad. Food Control 57, 105-109. doi: 10.1016/j.foodcont.2015.03.037

USFDA (2011). Food Safety for Pregnant Women. Available online at: https://www. fda.gov/food/foodborneillnesscontaminants/peopleatrisk/ucm312704.html

Vijayanandraj, S., Brinda, R., Kannan, K., Adhithya, R., Vinothini, S., Ssenthil, K., et al. (2014). Detoxification of aflatoxin B1 by an aqueous extract from leaves of Adhatoda vasica Nees. Microbiol. Res. 169, 294-300. doi: 10.1016/j.micres.2013.07.008

Walden, W. C., and Hentges, D. J. (1975). Differential effects of oxygen and oxidation-reduction potential on the multiplication of three species of anaerobic intestinal bacteria. Appl. Microbiol. 30, 781-785.

Yusop, S. M., O’Sullivan, M. G., Kerry, J. F., and Kerry, J. P. (2010). Effect of marinating time and low $\mathrm{pH}$ on marinade performance and sensory acceptability of poultry meat. Meat Sci. 85, 657-663. doi: 10.1016/j.meatsci.2010.03.020

Zhang, S., Zhang, M., Fang, Z., and Liu, Y. (2017). Preparation and characterization of blended cloves/cinnamon essential oil nanoemulsions. LWT Food Sci. Technol. 75, 316-322. doi: 10.1016/j.lwt.2016.08.046

Conflict of Interest Statement: The authors declare that the research was conducted in the absence of any commercial or financial relationships that could be construed as a potential conflict of interest.

Copyright (c) 2017 Shukla, Ahirwal, Bajpai, Huh and Han. This is an open-access article distributed under the terms of the Creative Commons Attribution License (CC $B Y)$. The use, distribution or reproduction in other forums is permitted, provided the original author(s) or licensor are credited and that the original publication in this journal is cited, in accordance with accepted academic practice. No use, distribution or reproduction is permitted which does not comply with these terms. 